\title{
ANSYS CFX STUDY OF AERODYNAMIC CHARACTERISTICS DURING BLADE PROFILE ROTATION
}

\author{
Andrey Yu. Proskurin, Yulia G. Zheglova \\ M oscow State University of Civil Engineering, M oscow, RUSSIA
}

\begin{abstract}
Currently, wind energy is one of the most developing areas, which is primarily due to the absence of emissions of harmful substances into the atmosphere. Wind power allows providing electricity to remote areas, where fuel delivery, as well as the construction of thermal power plants is laborious and expensive. The effective development of wind turbines should solve the following tasks: the creation of the necessary driving force and the possibility of using a high coefficient of wind energy, which does not contradict the maintenance of the ecological balance of the territory. A n electric generator for a household wind turbine must provide electricity in a wide range of rotation speeds and be able to work independently without automation and external energy sources. The study of the numerical implementation of the method of aerodynamic analysis of the wind turbine blade in rotational motion in the ANSYS CFD software package is by far the most promising and dynamically developing direction in the field of aerodynamics calculations. The results of approbation of the mixed calculation method using a dynamically variable and stationary finite-volume mesh are presented. The use of a mixed design scheme allows for calculations of wind turbines inside the building, while it becomes possible to minimize the required power for the study.
\end{abstract}

Keywords numerical simulation, aerodynamic processes, A nsys CFD, energy efficiency, alternative energy sources in construction, wind turbine, wind turbine blade, navier-stokes equations.

\section{ИССЛЕДОВАНИЕ АЭРОДИНАМИЧЕСКИХ ХАРАКТЕРИСТИК ПРИ ВРАЩЕНИИ ПРОФИЛЯ ЛОПАСТИ B ANSYS CFX}

\author{
А.Ю. Проскурин, Ю.Г. Жеглова \\ Московский Государственный Строительный Университет, Москва, РОССИЯ
}

\begin{abstract}
Аннотация. В настоящее время ветроэнергетика является одним из наиболее развивающихся направлений, что обусловлено, прежде всего, отсутствием выбросов вредных веществ в атмосферу. Ветроэнергетика позволяет обеспечить электроэнергией отдаленные районы, где доставка топлива, а также строительство тепловых электростанций трудоемки и затратны. Эффективное развитие ветроэнергетики должно решать следующие задачи: создание необходимой движущей силы и возможность использования высокого коэффициента использования энергии ветра, что не противоречит поддержанию экологического баланса территории. Электрогенератор для бытовой ветроустановки должен обеспечивать электроэнергию в широком диапазоне скоростей вращения и иметь возможность автономной работы без автоматики и внешних источников энергии. Исследование численной реализации метода аэродинамического анализа лопасти ветрогенератора во вращательном движении в программном комплексе ANSY S CFD на сегодняшний день является наиболее перспективным и динамично развивающимся направлением в области расчетов аэродинамики. Предварительно представлены результаты апробации смешанного метода расчета с использованием динамически изменяемой и стационарной конечно-объемной сетки. Использование смешанной расчетной схемы позволяет проводить расчеты ветровых турбин внутри здания, при этом появляется возможность минимизировать необходимую для исследования мощность.
\end{abstract}

Ключевые слова: численное моделирование, аэродинамические процессы, A nsys CF D, энергоэффективность, альтернативные источники энергии в строительстве, ветротурбина, лопасть ветротурбины,

уравнения Навье-Стокса. 


\section{INTRODUCTION}

The task of creating energy-independent buildings in the modern world is very important for the whole world. The resources of the earth are inexorably running out and mankind needs to place great emphasis on the development of new alternative energy sources. M odern architectural solutions in the construction of metropolitan areas seek to use high-tech photovoltaic facades and flexible solar membranes to obtain the solar energy needed for the construction of capital construction projects. Through the combined use of wind and solar energy, we have the opportunity to design a building that integrates different methods of generating clean energy, which, in turn, will bring the building to its intended full self-sufficiency in electricity.

\section{$1 \quad$ M aterials and methods}

\subsection{Problem definition}

To solve the problem of assessing the aerodynamic characteristics, a single-blade orthogonal highefficiency turbine was adopted. (US patent $\mathrm{V}$ ictor Lyatkher, US 8007235 B1, A ugust 30, 2011, RF patent 2426911 C1). Since the profile of the investigated blade corresponds in cross-section with the aviation profile NACA-0021, it was decided to accept the geometric characteristics according to the reference materials. [3] Fig. 1 shows a crosssection of the blade profile under investigation.

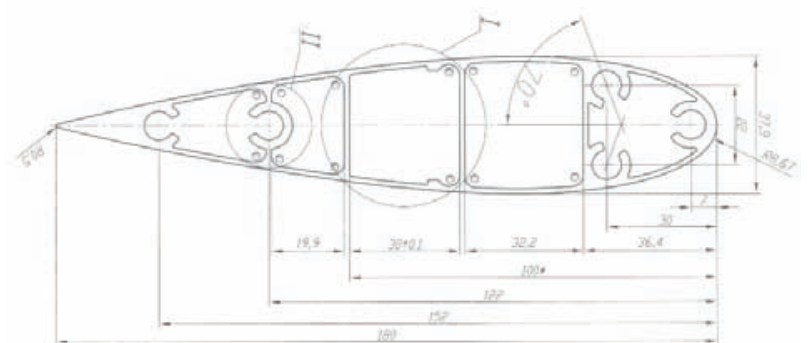

Figure 1. The cross-section of the blade profile under investigation

The aim of this work is to test the technique of numerical simulation of a rotating blade under the influence of an aerodynamic load in an unsteady turbulent flow in a two-dimensional setting. The problem of this installation is the occurrence of vibrations during the rotation of the blade at the points of attachment to the pedestal. At the moment, the study consists in determining the aerodynamic characteristics and an average assessment of the energy efficiency of the installation. As a research method, we used computer simulation of air flow around a wind turbine blade in the ANSY S software package [13].

In this work, this method takes into account the position of the blade in time, analyzing the equations of the translational and rotational motion of a rigid body. The solution of the unsteady Navier-Stokes equation is carried out at each calculated time, taking into account the previous results obtained at the previous step. This technique is very time consuming and resource consuming, but it allows you to analyze the behavior of the flow when flowing around a rotating body[11].

\subsection{Stages of the G rid Convergence Study}

Since there is no data on which it appears possible to determine the parameters of the calculated grid, it was concluded that it is necessary to conduct a series of verification calculations. The geometrical parameters of the grids can be seen in Table 1.

Using the built-in A nsys Workbench M eshing module, a tetraidal mesh was created. In all cases, the mesh size in the cylinder area and in the tail area the mesh has the same dimension of $0.06 \mathrm{~m}$; in the outer area, the dimension was taken equal to $0.75 \mathrm{~m}$. The problem was solved for four variants of the computational grid in order to find the optimal parameters of the computational grid. For the results to be accurate, it is necessary to create a boundary layer area all along the blade profile. The dimension of the boundary layer was determined based on the profile geometry, Reynolds number and turbulence model [4]. 
Table 1. Characteristics of computational grids

\begin{tabular}{cccccc}
\hline Model & $\begin{array}{c}\text { Hydraulic } \\
\text { diameter }\end{array}$ & $\begin{array}{c}\text { Reynolds } \\
\text { number }\end{array}$ & $\begin{array}{c}\text { Estimated } Y \\
+\end{array}$ & $\begin{array}{c}\text { Estimated dis- } \\
\text { tance from the } \\
\text { wall }\end{array}$ & $\begin{array}{c}\text { Thickening of the } \\
\text { mesh in the longi- } \\
\text { tudinal direction }\end{array}$ \\
\hline 1 & 0.38 & $5.0 \mathrm{e}+4$ & 1 & $1.3 \mathrm{e}-4$ & $1.0 \mathrm{e}-2$ \\
2 & 0.38 & $5.0 \mathrm{e}+4$ & 8 & $1.0 \mathrm{e}-3$ & $1.0 \mathrm{e}-3$ \\
3 & 0.38 & $5.0 \mathrm{e}+4$ & 40 & $5.0 \mathrm{e}-3$ & $5.0 \mathrm{e}-2$ \\
4 & 0.38 & $5.0 \mathrm{e}+4$ & 50 & $6.3 \mathrm{e}-3$ & $1.0 \mathrm{e}-2$ \\
5 & 0.38 & $5.0 \mathrm{e}+4$ & 80 & $1.0 \mathrm{e}-2$ & $1.0 \mathrm{e}-2$ \\
\hline
\end{tabular}

Table 2-3 show the results of the verification teristics at different geometric characteristics tasks. The tables show the aerodynamic charac- and different $Y+$ coefficients.

Table 2. Comparison of aerodynamic coefficients with experimental data $(\mathrm{Cd}, \mathrm{Cl}, \mathrm{C} \mathrm{m})$ for all calculation options $(Y+=1, Y+=40, Y+=50, Y+=80)$.

\begin{tabular}{cccccccccc}
\hline $\mathrm{Y}+$ & $\begin{array}{c}\mathrm{Cd} \\
\text { (exper- } \\
\text { iment) }\end{array}$ & $\begin{array}{c}\mathrm{Cd} \\
\text { (pay } \\
\text { ment) }\end{array}$ & $\begin{array}{c}\mathrm{Cd} \\
\text { Error }\end{array}$ & $\begin{array}{c}\mathrm{Cl} \\
\text { (experi- } \\
\text { ment) }\end{array}$ & $\begin{array}{c}\mathrm{Cl} \\
\text { (pay } \\
\text { ment) }\end{array}$ & $\begin{array}{c}\mathrm{Cl} \\
\text { Error }\end{array}$ & $\begin{array}{c}\mathrm{Cm} \\
\text { (experi- } \\
\text { ment) }\end{array}$ & $\begin{array}{c}\mathrm{Cm} \\
\text { (pay- } \\
\text { ment) }\end{array}$ & $\begin{array}{c}\mathrm{Cm} \\
\text { Error }\end{array}$ \\
\hline 1 & 0.042 & 0.029 & $-30.9 \%$ & 0.79 & 0.469 & $-40.6 \%$ & -0.045 & -0.018 & $-60 \%$ \\
40 & 0.042 & 0.024 & $-42.85 \%$ & 0.79 & 0.7 & $-11.39 \%$ & -0.045 & -0.028 & $-37.7 \%$ \\
50 & 0.042 & 0.039 & $-19.04 \%$ & 0.79 & 0.72 & $-8.86 \%$ & -0.045 & -0.039 & $13.6 \%$ \\
80 & 0.042 & 0.0323 & $-23.09 \%$ & 0.79 & 0.749 & $-5.189 \%$ & -0.045 & -0.03 & $-33.3 \%$ \\
\hline
\end{tabular}

Table 3. Comparison of aerodynamic coefficients $(\mathrm{Cd}, \mathrm{Cl}, \mathrm{Cm})$ for all calculation options $(Y+=1, Y+=40, Y+=50, Y+=80)$.

\begin{tabular}{cccccccccc}
\hline$Y+\begin{array}{c}50 \\
\text { (Refer- } \\
\text { ence) }\end{array}$ & 1 & Error & $\begin{array}{c}50 \\
\text { (Refer- } \\
\text { ence) }\end{array}$ & 40 & Error & $\begin{array}{c}50 \\
\text { (Refer- } \\
\text { ence) }\end{array}$ & 80 & Error \\
\hline $\mathrm{Cd}$ & 0.034 & 0.029 & $20.8 \%$ & 0.024 & 0.024 & $0 \%$ & 0.034 & 0.0223 & $-7.1 \%$ \\
$\mathrm{Cl}$ & 0.72 & 0.469 & $-34.9 \%$ & 0.72 & 0.7 & $-2.7 \%$ & 0.72 & 0.749 & $4.1 \%$ \\
$\mathrm{Cm}$ & -0.039 & -0.02 & $-37.8 \%$ & -0.039 & -0.03 & $-3.4 \%$ & -0.039 & -0.03 & $7.1 \%$ \\
$\mathrm{Cd}$ & 0.034 & 0.029 & $20.8 \%$ & 0.024 & 0.024 & $0 \%$ & 0.034 & 0.0223 & $-7.1 \%$ \\
\hline
\end{tabular}

A fter analyzing and comparing the results of the calculated parameters of CFD calculations with the results presented in the source [3], the $Y+$ 50 model is the most accurate for the performed non-stationary calculation based on the previous experience, which showed the smallest error in determining the aerodynamic coefficients in aggregate. In the case of estimating the drag coefficient, the largest error is $-46.9 \%$, the lift coefficient is $-40.6 \%$, and the lift coefficient is $-60 \%$. As a result of verification studies, the smallest discrepancy in criterion parameters with exper- 
imental data was obtained for the design case with $Y+=50$, therefore, it was decided to use this mesh as a design mesh for modeling a rotating blade under the influence of an aerodynamic load.

\subsection{B oundary and initial conditions.Calculation parameters}

The calculated geometry is presented in the form of a circle, which makes it possible to investigate the problem at different angles of air flow incursion. The flow velocity was assumed to be $15 \mathrm{~m} / \mathrm{s}$ with a percentage of turbulence up to $7 \%$. On both sides of the model, the conditions were built so as to take into account the curvature of the circle and simulate the flowing perpendicular to the blade of the wind turbine. On the lower part of the model, "slip walls" conditions were adopted (FreeslipWall, $\mathrm{U}=\mathrm{V}=\mathrm{W}=$ $0 \mathrm{~m} / \mathrm{s}$ ). Open boundary conditions were set on the upper part. The RigidBody Solution was used to solve the blade rotation problem with the possibility of rotation with respect to the Z-axis. The cylindrical domain was created as a subdomain with adjustment of the finite element mesh recalculation due to blade rotation. The subdo- main, domain interfaces, and vane must share the same air characteristics. This is necessary because the inner cylinder and solid must move and rotate at the same speed to properly isolate the motion. All relative motion between the inner cylinder and vane will be eliminated, resulting in a null grid deformation inside the inner cylinder. [10].

The interface for one domain has been changed to limit the rotational movement of the mesh surrounding the subdomain. The mesh located on the inner cylindrical interface of the domain will have the same physical properties as in the solid form. Since the rotation cannot start without outside help, the initial angular velocity was initialized, no other external accelerations were initialized.

The interface of the second domain was configured in such a way that the air flow freely and without loss of properties passed from one computational domain to another. Both areas of a larger radius and a smaller one are stationary and do not require special settings for a finitevolume mesh. A visualization of the calculation model can be seen in Fig. 2.

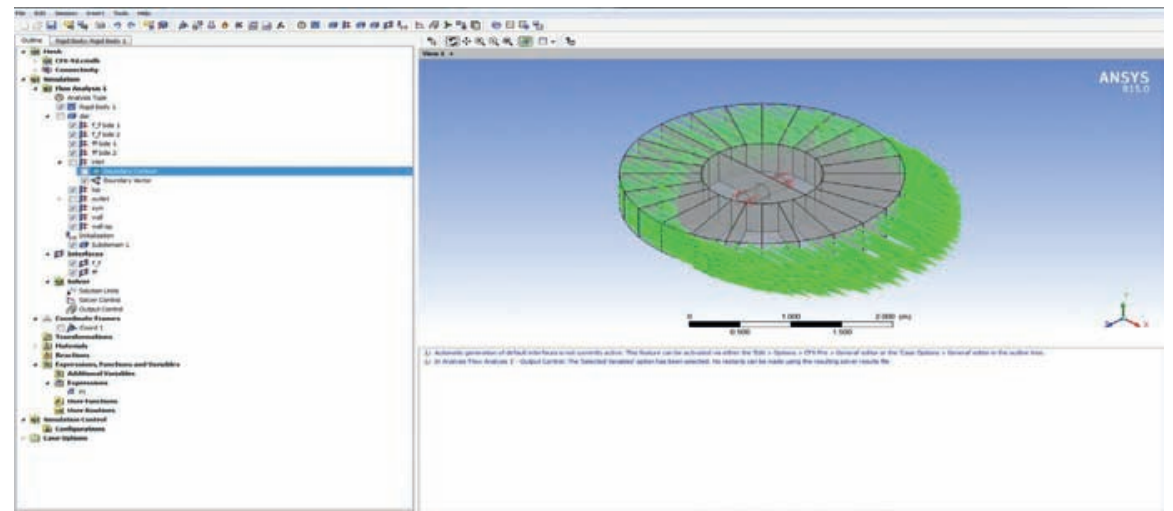

Figure 2. Calculation in the CFX software package (boundary conditions)

\section{Results of thestudy}

\subsection{Results of computer simulations in ANSYS CF D}

The calculations were carried out in a threedimensional non-stationary setting. The follow- ing basic physical characteristics of the flow are given for aerodynamic calculations $R e=50,000$. Fig. 3-7 show the main results of computational studies performed in the rotation of the blade of the wind turbine at different moments of time, the analysis of aerodynamic characteristics. 


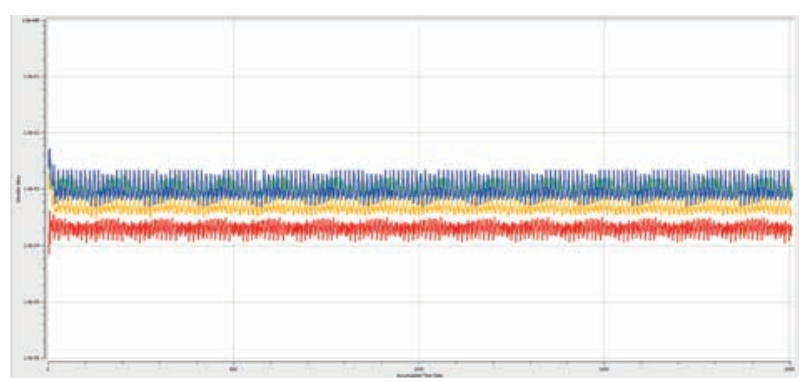

Figure 3. Calculation in the CFX software package ( $M$ asses and M oments)

Fig. 4-5 show the distribution of pressure values at different points in time. The figures show the change in blade position over time, leading to different pressure patterns on the profile itself. It can be seen that the pressure reaches its maximum value at the points where the profile experiences the maximum airflow resistance.

Fig. 8 shows graphs of frequencies of aerodynamic forces as the blade rotates

The graphs of the investigated forces show the non-stationarity of the modeled process, each wave corresponds to 1 rotation of the blade.

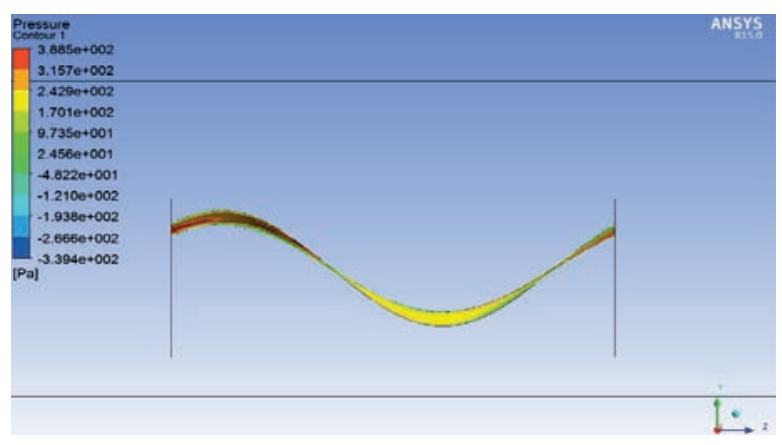

Figure 4. I sofield of pressures on the blade (frontal part) at time moment $0.5 \mathrm{sec}$

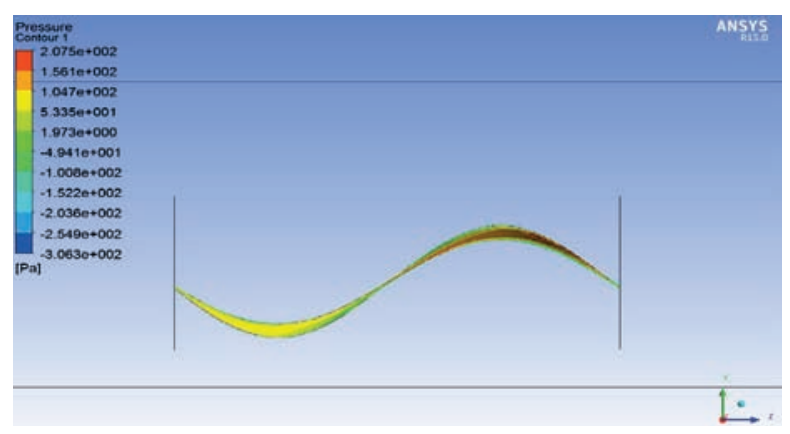

Figure 5. I sofield of pressures on the blade (frontal part) at time moment $5.5 \mathrm{sec}$

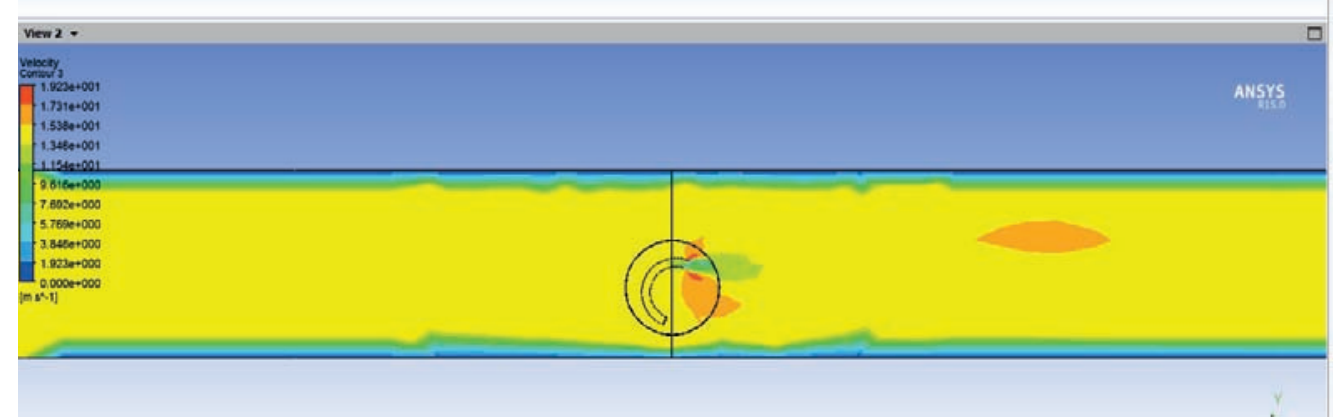

Figure 6. I sofields of pressures in the common domain at the time of $2.5 \mathrm{sec}$

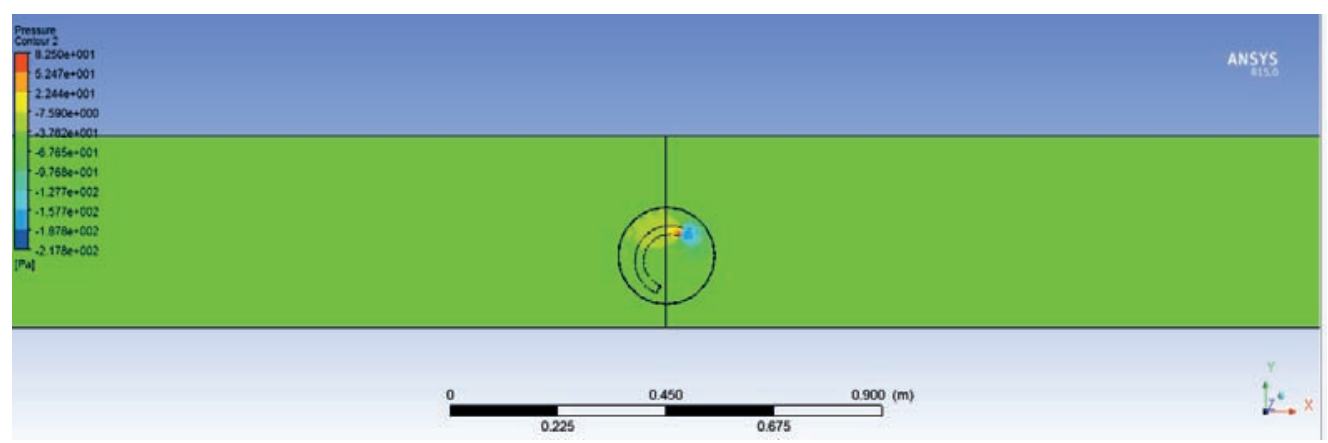

Figure 7. I sofields of velocities in the common domain at the time of $2.5 \mathrm{sec}$ 


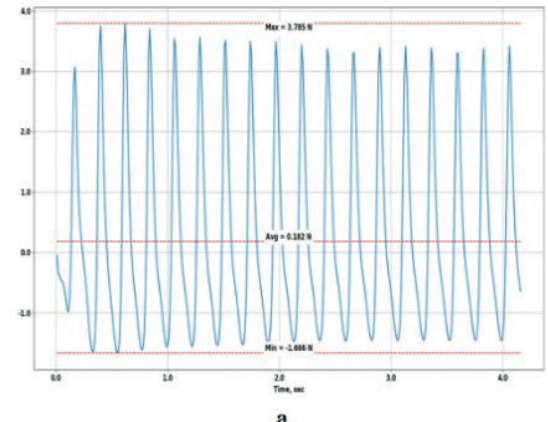

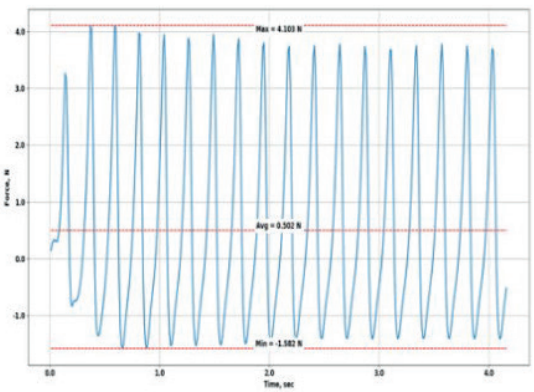

Figure 8. Graphs of the investigated aerodynamic characteristics during the rotation of the blade a) Lift force in time b) The force of frontal resistance in time

\section{Energy efficiencycalculation}

Unfortunately, the initial data is not enough for a complete analysis of energy efficiency data, however, the known dimensions make it possi- ble to determine the amount of energy generated based on the throwing area.

Table 4 shows the values of generated energy at different air flow velocities. These values are calculated based on the size of the swept area.

Table 4. Power G enerated Summary T able

\begin{tabular}{ccc}
\hline Flow rate, $\mathrm{m} / \mathrm{s}$ & A ir density, $\mathrm{kg} / \mathrm{m3}$ & The amount of generated energy, $\mathrm{kW}$. \\
\hline 2 & 1.185 & 0.09 \\
5 & 1.185 & 1.475 \\
10 & 1.185 & 11.8 \\
15 & 1.185 & 39.8 \\
20 & 1.185 & 94.4 \\
25 & 1.185 & 184.3 \\
\hline
\end{tabular}

\section{DISCUSSION}

The analysis of frequencies, see Fig. 8, shows the coincidence with the rotational speed of the blade, while the rotational speed remains constant, the time of 1 revolution of the blade is 1.7 seconds. W hat can be said about the fact that the wind turbine rotates normally. The study shows the consistency of the method for calculating the blade, taking into account the take-off of the blade from the effect of the air flow.

A s can be seen from Table 4, at a flow rate of 25 $\mathrm{m} / \mathrm{s}$, the blade almost completely allows a small house to be supplied with energy. This allows us to conclude that a large number of such generators will be able to replace the current "harmful" power plants with more environ- mentally friendly ones. At the current stage, it was possible to fully implement the dynamic calculation, with the implementation of the rotation of the wind turbine blade under the action of the air flow. The use of a mixed calculation will allow further research into the integration of a wind turbine blade into the structure of a building. W ith the creation of geometric design features that will increase the oncoming flow velocity.

\section{CONCLUSIONS}

The solution of the current problems showed the consistency of the project and its relevance, in the future it is necessary to carry out a numerical 
solution of a coherent problem, which will consist of calculating the bearing capacity of the building, taking into account the aerodynamic component and parallel calculation of the wind turbine for energy efficiency and aerodynamic characteristics and transmission of vibrations from the rotation of the wind generator.

\section{REFERENCES}

1. Garbaruk A.V., Strelets M.Kh., Shur M.L.: Turbulence Modelling in Combined Flow Calculations. Tutorial, St. Petersburg (2012).

2. Lutsky A.E., Severin A.V. The simplest implementation of the method of wall functions. Preprints of the Keldysh Institute M.V. Keldysh,38 (2013).

3. Handbook of Aviation Profiles.

4. Schlichting, G. Boundary Layer Theory. Nauka,Moscow (1974).

5. Gorlin S.M. Experimental Aerodynamics. Vysshaya Shkola, Moscow (1970).

6. ANSYS, Inc., "ANSYS 15 Help", 2014.

7. Tominaga, Y., Mochida, A. AIJ guidelines for practical applications of CFD to pedestrian wind environment around buildings. Journal of Wind Engineering and Industrial Aerodynamics 96, 1749-1761 (2008).

8. Kozhukhov Yu.V., Reshetnikova L.V., Zhalmurzieva G.I. Numerical experiment in software package ansys cfx for impeller and bladeless diffuser model of medium frequency centrifugal compressor stage. Polytechnic University Press, St. Petersburg (2012).

9. Kozhukhov Yu.V., Tribunskaya K.S. Numerical experiment and data analysis of axial turbocharger compressor stage calculation in ansys cfx software package. Polytechnic University Press, St. Petersburg (2012).ANSYS CFX 14.5: Руководство пользователя / ANSYS Inc., 2014.

10. Roach, P. Computational Fluid Dynamics. Mir, Moscow (1980).

11. Federova. N., ValgerS., Danilov M., Zakharova Y. Fundamentals of Ansace 17. DMK Publishing House (2017).
12. Kozhukhov, Yu.V., Lebedev A.A., Danilishin A.M., Davletgareev E.V. Auditing Characteristics of Wind Turbine Generators Using CFD Modeling on Supercomputer. Polytechnic University Press (2016).

13. Afanasieva N. I., Lantsova I. Yu. Numerical modelling of elastic structure behaviour under transient fluid flow excitation. Proceedings of the AIP 1800 Conference, 1-10 (2017).

14. Simiu E., Scanlan R. Influence of Wind on Buildings and Structures. Stroyizdat,Moscow (1984).

15. Savitsky G.A. Wind loads on structures. Publishing House of Literature on Construction, Moscow (1972).

16. S. Andreev. V., Bondarev A.E., Bondarenko A.V., Vizilter Y., Galaktionov V.A., Gudkov A.V., Zheltov S.Yu., Zhukov V.T., Ilovajskaya E.B., Kniaz V.A., Manukovsky K.V., Novikova N.D., Ososkov M.V., Silaev N.Yu., Feodoritova O.B., Bondareva N.A.: Simulation and Visualization of the Complex Shape Blade Assembly in Power Plant. Journal of Scientific Visualization 4(7), 1-12 (2015).

17. Kholshchevnikov K.V.Theory and Calculation of Aircraft Blades. Mashinostroenie, Moscow (1970).

\section{СПИСОК ЛИТЕРАТУРЫ}

1. Гарбарук А.В., Стрелец М.Х., Шур М.Л. Моделирование турбулентности в расчетах сложных течений. Учебное пособие. // СПб., 2012.

2. А. Е. Луцкий, А. В. Северин, "Простейшая реализация метода пристеночных функций”, Препринты ИПМ им. М. В. Келдыша, 2013, 038, 22 с.

3. Справочник Авиационных Профилей.

4. Strojniški vestnik - Journal of Mechanical Engineering 60(2014)12 Received for review: 2014-02-03 @ 2014.

5. Шлихтинг $\boldsymbol{\Gamma}$. Теория пограничного слоя $36 \mathrm{c}$. 
6. Берг О.И. Принципы построения и элементы систем управления автономных комплексов электроснабжения на возобновляемых источниках энергии, 2015, 88 с.

7. Горлин С.М. Экспериментальная аэродинамика. // М.: «Высшая школа», 1970. -423 с.

8. ANSYS, Inc., “ANSYS 15 Help”, 2014.

9. MInternational Journal for Computational Civil and Structural Engineering

10. Tominaga, Y., Mochida, A. AIJ guidelines for practical applications of CFD to pedestrian wind environment around buildings // Journalof Wind Engineering and Industrial Aerodynamics, Volume 96, Issues 10-11,October-November 2008, p. 1749-1761.

11. Кожухов Ю.В., Решетникова Л.В., Жалмурзиева Г.И. Численный эксперимент в программном комплексе ansyscfx для paбочего колеса и безлопаточного диффузора модельной центробежной компрессорной ступени средней быстроходности. [XLI Неделя науки СПбГПУ.: материалы международной научно-практической конферен- ции. Ч. ІІІ.] -СПб.: (Изд-во Политехн. ун-та, 2012. $104 \mathrm{c})$

12. Кожухов Ю.В., Трибунская К.С. «Проведение численного эксперимента и анализ данных расчёта ступени осевого компрессора турбонаддува в программном комплексе ansyscfx.» // [XLI Неделя науки СПбГПУ.: материалы международной научно-практической конференции. Ч. III.] - СПб.: (Изд-во Политехн. ун-та, 2012. 102 c.)

13. Горлин С.М. Экспериментальная аэродинамика. // М.: «Высшая школа», 1970. - $423 \mathrm{c}$.

14. ANSYS CFX 14.5: User's Manual [Электронныйресурc] / ANSYS Inc., 2014. http://www. ansys.com

15. Руденко В.А. Разработка и исследование системы метрологического обеспечения измерений и учёта попутного нефтяного газа.

16. Роуч П. Вычислительная гидродинамика. // М.: Мир, 1980. - 616 с.
Zheglova Julia Germanovna, PhD in Technical Sciences, Associate Professor of Information Systems, Technologies and Construction Auto-mation Department, Moscow State University of Civil Engineering. Russian Federation, Moscow, Yaroslavskoe shosse 26k1. +7(495)287-49-19 (ext. 30-41) email: uliagermanov-na@yandex.ru ORCID - 00000001-8121-8535, ScopusID - 57202228987

Proskurin Yu. Andrei, Lecturer of Department of Informatics and Applied Mathematics, Mos-cow State Construction University. Russian Federation, Moscow, Yaroslavskoe shosse 26k1.8-495-183-59-94 email: proskurina-yu@ mgsu.ru
Жеглова Юлия Германовна, кандидат технических наук, доцент кафедры информационных систем, технологий и автоматизации в строительстве Московского Государственного строительного университета. Российская Федерация, г Москва Ярославское шоссе 26к1 . +7(495)28749-19 (доб. 30-41) email : uliagermanovna@yandex.ru ORCID - 0000-0001-8121-8535, ScopusID - 57202228987

Проскурин Андрей Юрьевич, преподаватель кафедра информатики и прикладной математики Московского Государственного строительного университета. Российская Федерация, г Москва, Ярославское шоссе 26к1 . 8-495-183-59-94 email : proskurina-yu@mgsu.ru 